\title{
EXPERIMENTAL STUDY OF SALTED FISH DRYING UNDER GREENHOUSE DRYER
}

\author{
Sidhi Sigit D.P.*, Pujianto Andreas, Prasetyo Djoko, Nurfauzi Akhmad, Muhfizar \\ Politeknik Kelautan dan Perikanan Sorong, Sorong, West Papua, Indonesia \\ *E-mail: sigit.deddy@kkp.go.id
}

\begin{abstract}
A parabolic roof, active solar greenhouse dryer was developed and tested. The greenhouse dryer was $6.5 \mathrm{~m} 2$ in area and $2.5 \mathrm{~m}$ high. The greenhouse cover was made of polyethylene and the floor made of concrete paving blocks. Experiments were conducted in the tropical area of Sorong, West Papua, Indonesia $\left(0^{\circ} 49^{\prime} S\right.$ and $\left.131^{\circ} 14^{\prime} \mathrm{E}\right)$ over 3 days in December 2017. Variation of the salting method (brine and dry salting) and salt concentration $(0.2,0.25$ and $0.3 \mathrm{~g} \mathrm{NaCl} / \mathrm{g}$ ) were investgated to determine the effect of those variations on the moisture content and the drying rate of salted yellowtail fish. The temperatures of the greenhouse room and the ambient air, relative humidity, global solar radiation inside the greenhouse dryer and the velocity of the exhaust air were recorded hourly during the fish drying. Those data were used to determine the thermal efficiency of the greenhouse dryer. The temperature differences of the air inside the greenhouse and the ambient air reached $15.8^{\circ} \mathrm{C}$. The temperature and relative humidity inside the greenhouse varied from $32^{\circ} \mathrm{C}$ to $51.4^{\circ} \mathrm{C}$ and $24.9 \%$ to $58.71 \%$, respectively. This was within the recommended range for fish drying. In the first $8 \mathrm{hr}$ of the dying process, a salt concentration of $0.2 \mathrm{~g} \mathrm{NaCl} / \mathrm{g}$ gave the fastest drying rate for both salting methods. For salted yellowtail fish the drying rate, the dry salting method was slower than the brine one.
\end{abstract}

\section{KEY WORDS}

Greenhouse dryer, salted fish, salting method, salt concentration.

Indonesia is one of the largest fisheries in the world, with annual production reaching around 6 million tons (Fisheries, 2013). In Indonesia, the most consumed fishery product is fish. Fish is one of the most important foodstuffs because of its high nutritional value and protein content. It has high-quality animal protein, providing around $6 \%$ of the global protein requirement and $16 \%$ of the total animal protein (Jain, 2006). However, fresh fish contains up to $80 \%$ water and is a highly perishable material (Bala and Mondol, 2001). If fresh fish is not directly consumed or processed into finished products, the fish will quickly decay and become waste (Sidhi et al., 2017). Prompt preservation of fish prevents decay and maintains the quality of the fish. This can be done by salting, freezing, smoking, frying or drying. The commonest fish preservation method in Indonesia are salting followed by drying.

One of the oldest techniques for preserving fish is salting. It was in use long before drying, smoking, and marinating. Dried salted fish demand in many countries of Southeast Asia is very high because of the simplicity of the process. It needs a minimum of capital investment and the product provides a cheap source of high-quality protein (Berhimpon et al., 1990). The salting process can be wet, dry or a combination of the two (Sobukola and Olatunde, 2011). Drying is a moisture removal process from a product, that involves heat and mass transfer. It can be done by open-air sun drying, firewood/fuel drying, electrical drying and solar drying (Tiwari, Tiwari and Al-Helal, 2016).

Salting followed by open-air sun drying is commonly used by traditional processors because it is cheaper and easily adaptable. Only a few traditional processors use solar drying. There have been a number of studies on salting and drying fish, both with open-air sun and solar drying. Sobukola and Olatunde (2011) studied the effect of salting techniques on the salt uptake and drying kinetics of African cat-fish (ACF). The effect of dry and brine salting on the salt uptake and drying kinetics of ACF was investigated by using a convective dryer. Berhimpon et al. (1990) investigated the salting and drying behavior of low-fat yellowtail. They used $15 \%, 21 \%$ and saturated salt brine solutions on salting experiments 
and dried the salted fish with different temperature and relative humidity using a mechanical dryer. Bala and Mondol (2001) investigated the performance of a greenhouse solar tunnel dryer for drying fish in Bangladesh. Bellagha et al. (2007) studied the salting and drying kinetics of sardines using a convective dryer to improve the quality of the traditional dried salted fish.

Although Bala and Mondol (2001) investigated the performance of solar tunnel dryers for drying fish, no work has been reported using a parabolic greenhouse for drying fish. Therefore, the aim of this study was to examine the effect of salting technique on the changes of the moisture ratio and drying rates for salted yellowtail fish in a parabolic greenhouse dryer.

\section{MATERIALS AND METHODS OF RESEARCH}

Experimental Setup. An active greenhouse dryer (See Figure 1) was installed at Politeknik Kelautan dan Perikanan Sorong ( $0^{\circ} 49^{\prime} \mathrm{S}$ and $\left.131^{\circ} 14^{\prime} \mathrm{E}\right)$, West Papua, Indonesia. The greenhouse was $3.25 \mathrm{~m}$ long, $2 \mathrm{~m}$ wide, and $2.5 \mathrm{~m}$ high and fixed in an East-West direction. The greenhouse cover was made of $0.05 \mathrm{~mm}$ thick polyethylene and concrete paving blocks $100 \mathrm{~mm}$ thick were used for the greenhouse floor. Two air inlet holes, each measuring $530 \mathrm{~mm} \times 145 \mathrm{~mm}$, were located near the door. For forced convection, six exhaust fans (12 V DC) were mounted on the back-wall opposite the door. Electrical energy for the exhaust fans was supplied by $2 \times 50 \mathrm{Wp}$ solar cells. The two drying trays $(2400 \mathrm{~mm} \times$ $650 \mathrm{~mm}$ ) inside the greenhouse were made of aluminium wire mesh and had a combined capacity of approximately $7.5 \mathrm{~kg}$.

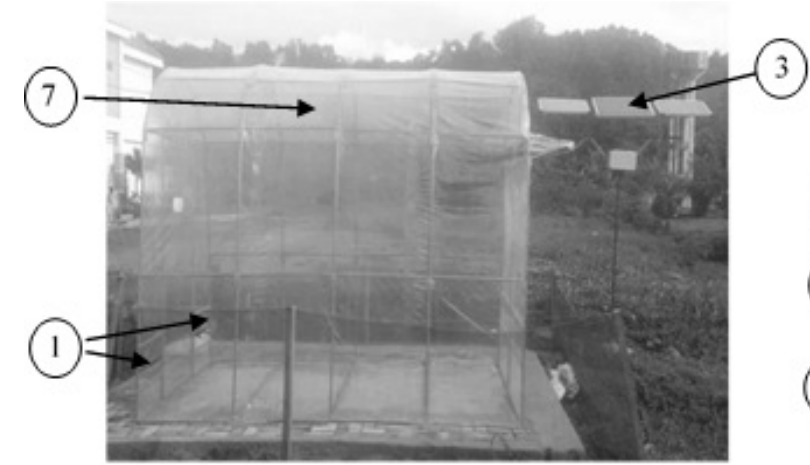

(a)

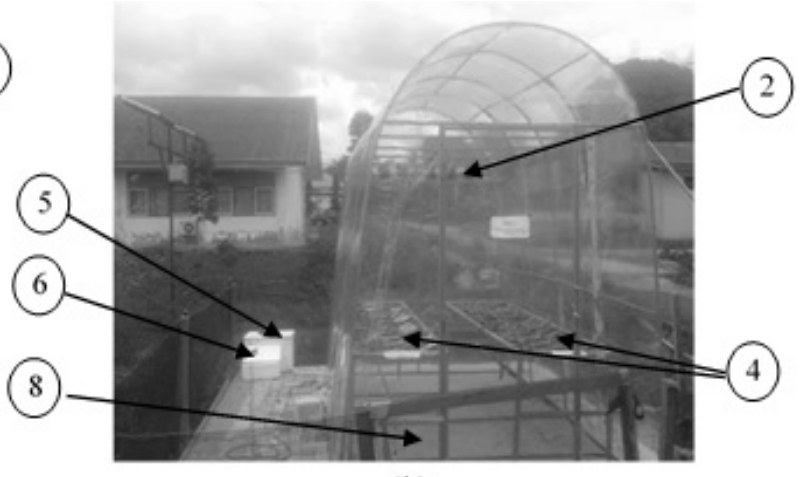

(b)

Figure 1 - Side (a) and front (b) views of the greenhouse dryer 1 - inlet holes; 2 - exhaust fans; 3 solar cells; 4 - trays; 5 - batteries; 6 - data logger; 7 - greenhouse cover; 8 - greenhouse floor.

Salted fish was dried to determine the effect of the salting technique on the drying process under the greenhouse dryer. This study used yellowtail fish. Fresh yellowtail fish were bought from local fisherman around the coast of Sorong. Fish were iced in an insulation box before salting. They were manually filleted on the back with a stainless-steel knife from near the tail to the head after they were washed using fresh water. The initial mass of each sample before salting was approximately $2500 \mathrm{~g}$. Brine and dry salting methods were carried out for the products. Salt concentrations for each salting method were 0.2, 0.25, and $0.3 \mathrm{~g}$ $\mathrm{NaCl} / \mathrm{g}$. Before the drying process, salted fish were kept in a plastic box for about $24 \mathrm{hr}$. The salted fish sample was dried in an electric oven for $24 \mathrm{~h}$ at $105^{\circ} \mathrm{C}$ to determine the dry mass after the drying process in the greenhouse dryer (Mujaffar and Sankat, 2005).

\subsection{Experimental Procedure}

The experiments were conducted over 3 days from 20-22 December 2017. The drying process was run for $8 \mathrm{hr}$ every day from 08.30 to 16.30. A pyranometer RK 200-04 (accuracy $\pm 5 \%$ ) was used for measuring solar radiation inside and outside of the greenhouse. Relative humidity and temperature inside and outside the greenhouse were measured using DHT 22 sensors. These sensors typically had accuracies of $\pm 0.5^{\circ} \mathrm{C}$ and $\pm 2 \%$ for the relative 
humidity and a resolution of $0.1^{\circ} \mathrm{C}$ and $0.1 \%$. The temperature of the fish was measured with an infrared thermometer with an accuracy of $\pm 2^{\circ} \mathrm{C}$. The air inlet velocity was measured using an anemometer with a resolution of $0.1 \mathrm{~m} / \mathrm{s}$ and an accuracy of $\pm 5 \%$. The mass of fish was measured using a digital balance with a resolution of $0.2 \mathrm{~g}$.

The pyranometer and DHT 22 voltage signals were hourly recorded using a data logger, which used an Arduino Mega board. The pyranometer was calibrated against a calibrated pyranometer by the manufacturer. The sensor of hygrometers in the DHT 22 were calibrated using saturated salt solution (sodium chloride) at approximately $30^{\circ} \mathrm{C}(75.09 \pm$ $0.11 \%$ ) (Greenspan, 1977). Air inlet velocity, mass, and temperature of fish were also manually recorded every $1 \mathrm{hr}$.

\section{RESULTS AND DISCUSSION}

Solar radiation was recorded hourly during the drying process for each of the 3 days, variations in outside and inside solar radiation are shown in Fig. 2. Outside solar radiation varied from 127.61 to $1048.72 \mathrm{~W} / \mathrm{m}^{2}$, while inside solar radiation varied from 70.46 to 998.29 $\mathrm{W} / \mathrm{m}^{2}$. Average solar radiation values on the first day were $703.21 \mathrm{~W} / \mathrm{m}^{2}$ (outside) and 615.06 $\mathrm{W} / \mathrm{m}^{2}$ (inside). These values were higher than for other days. Each day the highest solar radiation occurred between 11.30 and 12.30, except on the second day due to cloudy weather conditions. A significant decrease in solar radiation occurred on the third day from 13.30 to 16.30 , also due to cloudy weather conditions.

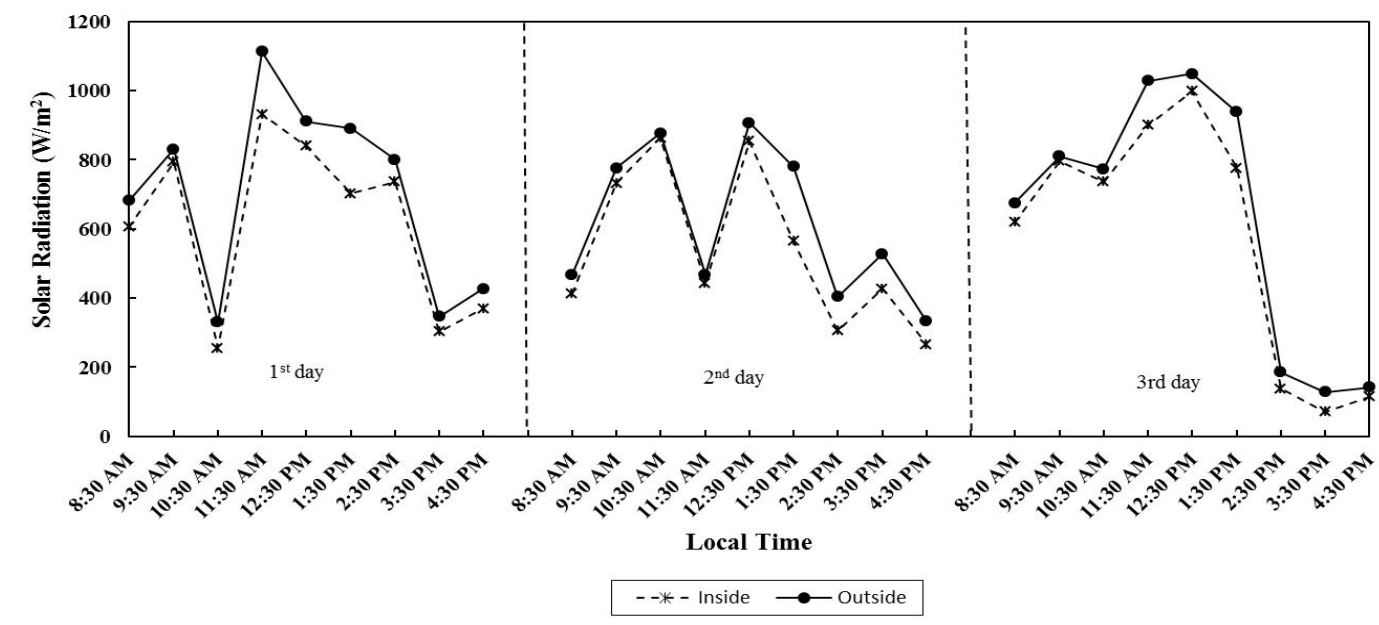

Figure 2 - Variations of solar radiation with the time of day during fish drying

Figure 3 shows the temperature and relative humidity of the air recorded every $1 \mathrm{hr}$. The temperature of the ambient air varied from $29.8^{\circ} \mathrm{C}$ to $39.0^{\circ} \mathrm{C}$ and the temperature of the greenhouse room varied from $32.0^{\circ} \mathrm{C}$ to $51.4^{\circ} \mathrm{C}$. The highest temperature $\left(51.4^{\circ} \mathrm{C}\right)$ in the greenhouse room occurred on the third day. The temperature of the greenhouse room did not exceed $70^{\circ} \mathrm{C}$, which is considered the maximum temperature for fish drying (Rahman, 2006; Hubackova et al., 2014). The difference between the temperature of greenhouse room and the ambient air varied from $2.2^{\circ} \mathrm{C}$ to $15.8^{\circ} \mathrm{C}$. The highest value was $15.8^{\circ} \mathrm{C}$ at 11.30 on the third day and the lowest value was $2.2^{\circ} \mathrm{C}$ at 15.30 on the third day. The relative humidity of the air is shown in Figure 4. The relative humidity of the ambient air varied from $43.26 \%$ to $82.15 \%$ while the relative humidity of the greenhouse room air varied from $24.9 \%$ to $58.71 \%$. Variations in the relative humidity (10-40\%) had no noticeable effects on the quality of the product (Rahman, 2006). The lowest relative humidity for greenhouse room air was $24.9 \%$ on the third day, while the relative humidity of ambient air was $47.01 \%$. 


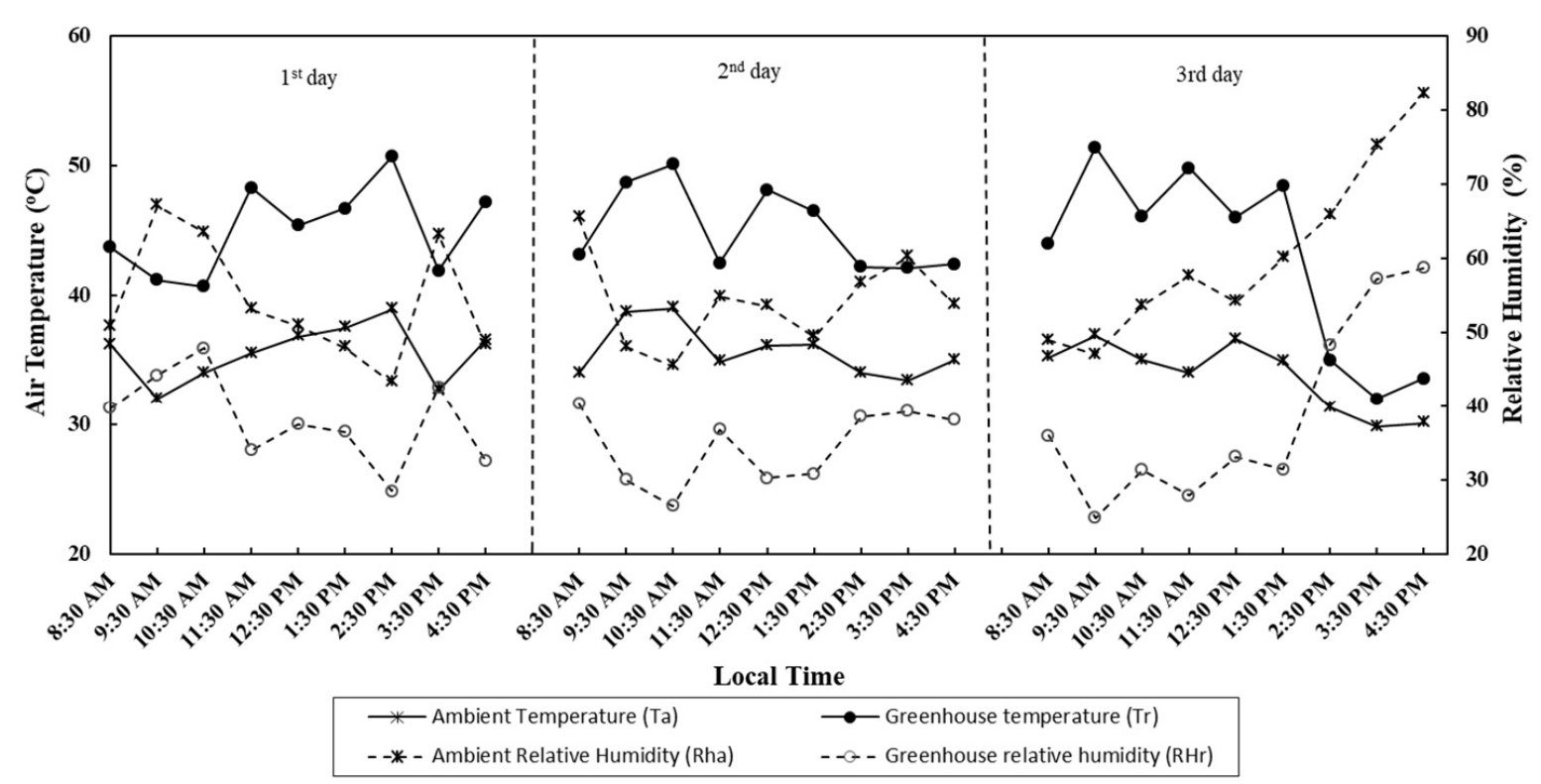

Figure 3 - Temperature and relative humidity of air variations during fish drying

The surface temperature of the salted fish during drying is shown in Figure 4. The average temperature for brine and dry salted fish, at concentrations of $0.2 \mathrm{~g} \mathrm{NaCl} / \mathrm{g}, 0.25 \mathrm{~g} \mathrm{NaCl} / \mathrm{g}$, $0.3 \mathrm{~g} \mathrm{NaCl} / \mathrm{g}$, were $48.19^{\circ} \mathrm{C}, 47.24^{\circ} \mathrm{C}, 45.68^{\circ} \mathrm{C}, 48.79^{\circ} \mathrm{C}, 50.66^{\circ} \mathrm{C}$, and $50.71^{\circ} \mathrm{C}$, respectively. The average surface temperature of the fish in the dry salting method was higher than for the brine salting method. For the brine salting method, the fish with $0.2 \mathrm{~g} \mathrm{NaCl} / \mathrm{g}$ salt concentration had the highest average surface temperature, while for the dry salting method, the fish with $0.3 \mathrm{~g} \mathrm{NaCl} / \mathrm{g}$ salt concentration had the highest average surface temperature.

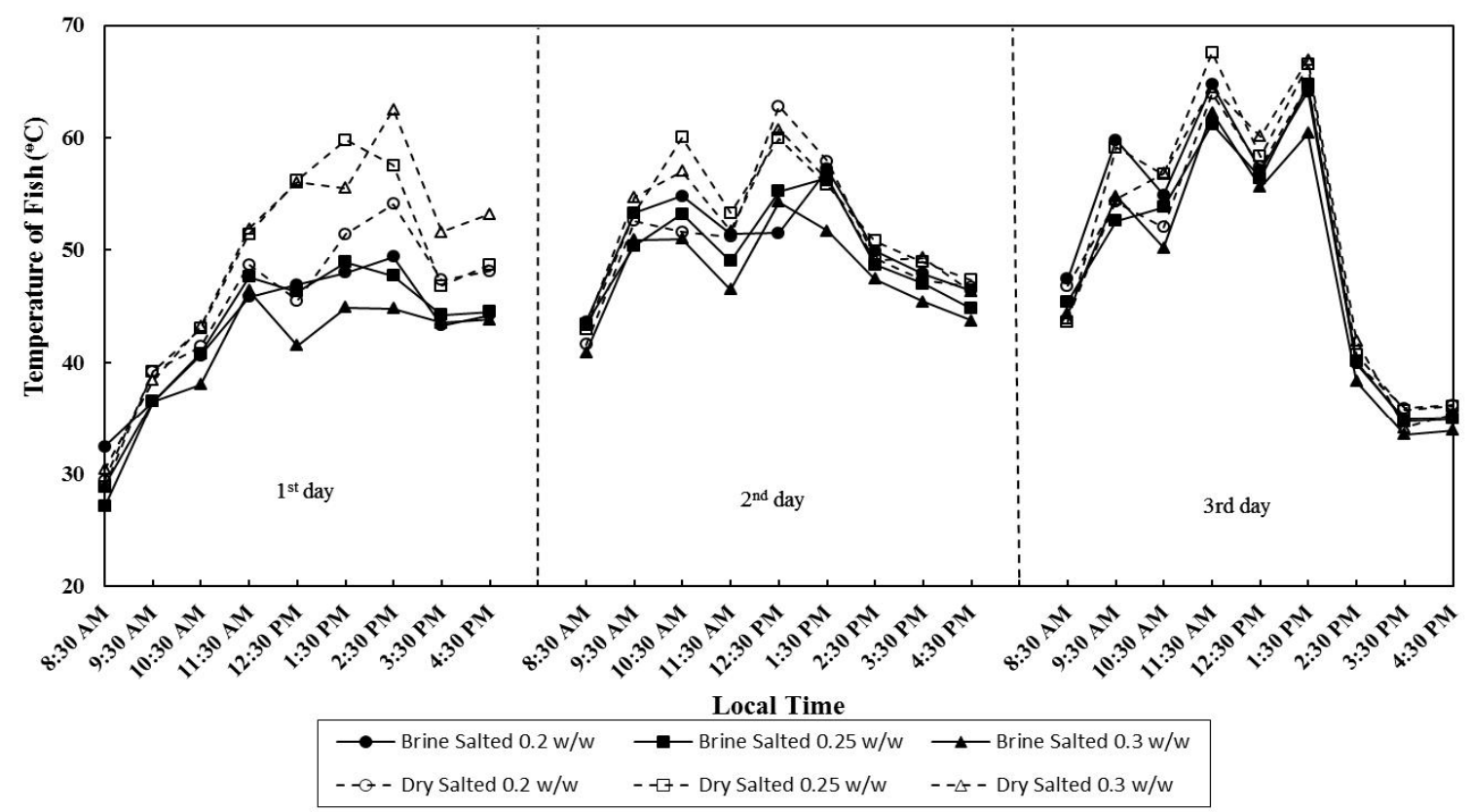

Figure 4 - Temperature of fish inside the greenhouse dryer

Figure 5 shows the moisture ratio of the fish with different salting methods and salt concentrations for the 24 hrs drying process in the greenhouse dryer. The moisture ratio $\left(M_{r}\right)$ can be determined using Eq. (1). Where $M$ is the moisture content, $M_{e}$ is the equilibrium moisture content and $M_{0}$ is the initial moisture content. The moisture ratio was calculated on 
a dry basis. The moisture ratio of the fish salted with brine decreased faster than that of the fish that were dry salted. The average air temperature and relative humidity inside the greenhouse dryer were $44.36^{\circ} \mathrm{C}$ and $37.14 \%$, respectively. For the dry salting method, the decrease in the moisture ratio for the $0.3 \mathrm{~g} \mathrm{NaCl} / \mathrm{g}$ salt concentration was slower than for the $0.25 \mathrm{~g} \mathrm{NaCl} / \mathrm{g}$ and $0.2 \mathrm{~g} \mathrm{NaCl} / \mathrm{g}$ salt concentrations for the $24 \mathrm{hrs}$ of the drying process. While the decrease in the moisture ratio for the $0.2 \mathrm{~g} \mathrm{NaCl} / \mathrm{g}$ salt concentration was faster than for the $0.25 \mathrm{~g} \mathrm{NaCl} / \mathrm{g}$ for $18 \mathrm{hrs}$ of the drying process. After further drying, the rate of decrease in the moisture ratio for the $0.25 \mathrm{~g} \mathrm{NaCl} / \mathrm{g}$ and $0.2 \mathrm{~g} \mathrm{NaCl} / \mathrm{g}$ concentrations tended to be similar. For the brine salting method there was an inversion point in the moisture ratio that was reached after about $12 \mathrm{hrs}$ of drying. The decrease in the moisture ratio for the $0.3 \mathrm{~g}$ $\mathrm{NaCl} / \mathrm{g}$ salt concentration was slower than for the other salt concentrations for the first $12 \mathrm{hrs}$ of the drying process. After further drying, the rate of decrease of the moisture ratio for the $0.3 \mathrm{~g} \mathrm{NaCl} / \mathrm{g}$ salt concentration was greater than for the other salt concentrations. The rate of decrease in the moisture ratio for the $0.25 \mathrm{~g} \mathrm{NaCl} / \mathrm{g}$ and $0.2 \mathrm{~g} \mathrm{NaCl} / \mathrm{g}$ salt concentrations were almost equal for the $24 \mathrm{hrs}$ of the drying process.

$$
M_{r}=\frac{M-M_{e}}{M_{0}-M_{e}}
$$

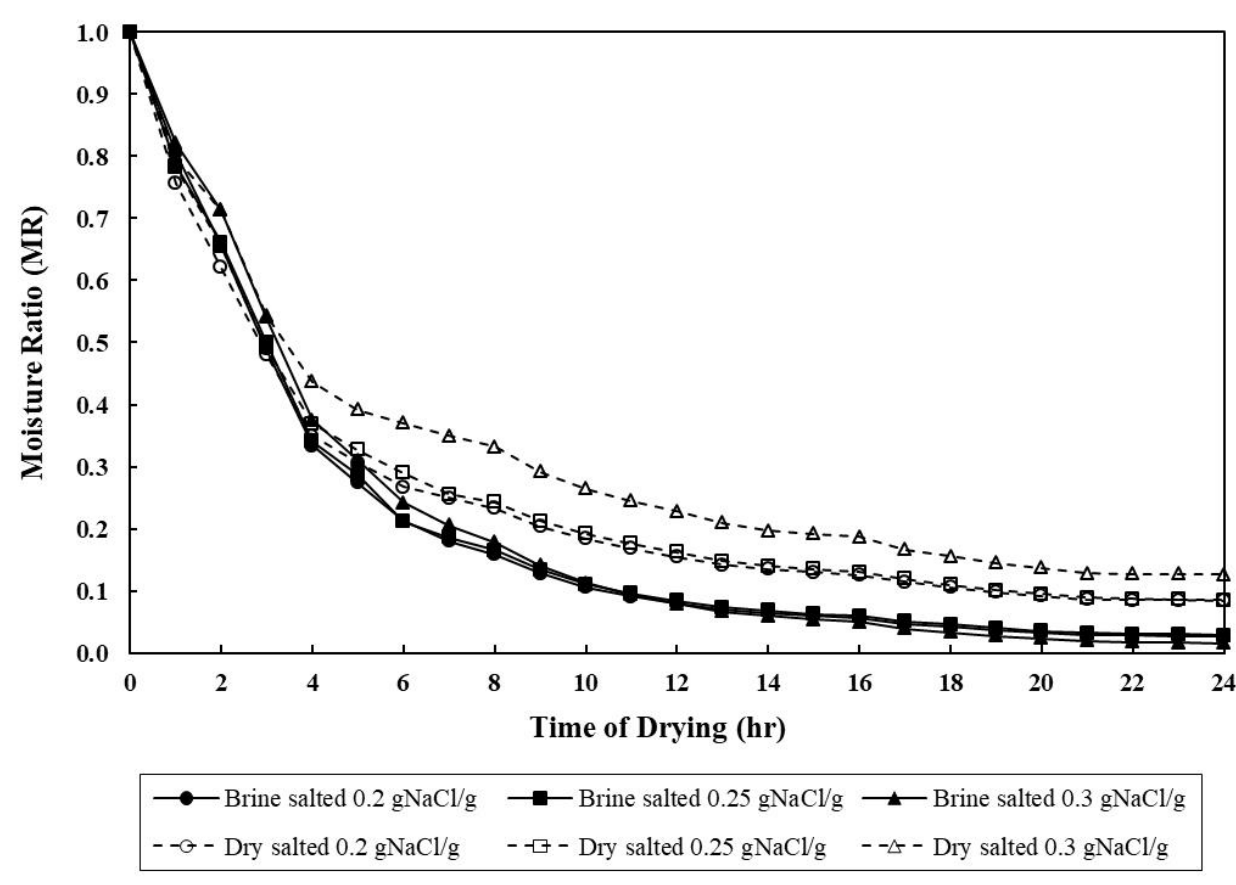

Figure 5 - Moisture ratio during drying process

In general, the drying rate reduces with time or with the reduction of the moisture content (Darvishi et al., 2013). The drying rate (DR) of salted fish was determined using Eq. (2) (Sobukola and Olatunde, 2011) and is shown in Figure 6, where $D R$ is the drying rate in $\mathrm{g} / \mathrm{g} \mathrm{db} / \mathrm{hr}, M_{t+d t}$ is moisture content at $t+d t$ in $\mathrm{g} / \mathrm{g} \mathrm{db}, M_{t}$ is the moisture content at time $t \mathrm{in} \mathrm{g} / \mathrm{g}$ $\mathrm{db}$ and $d t$ is time difference in hours. The drying rate continuously decreased with drying time increased. The drying rate of dry salting method was slower than brine salting method for the first $8 \mathrm{hrs}$ of the drying process. That can be explained that water motion from the inside to the surface of the fish was followed by salt migration during drying. When the initial salt concentration was greater, then water evaporation on the surface of the fish caused a crust formation. The crust that was on the surface of the fish, lessened the rate of water loss by making the surface of the fish less permeable (Bellagha et al., 2007; Sobukola and Olatunde, 2011). 


$$
D R=\frac{M_{t+d t}-M_{t}}{d t}
$$

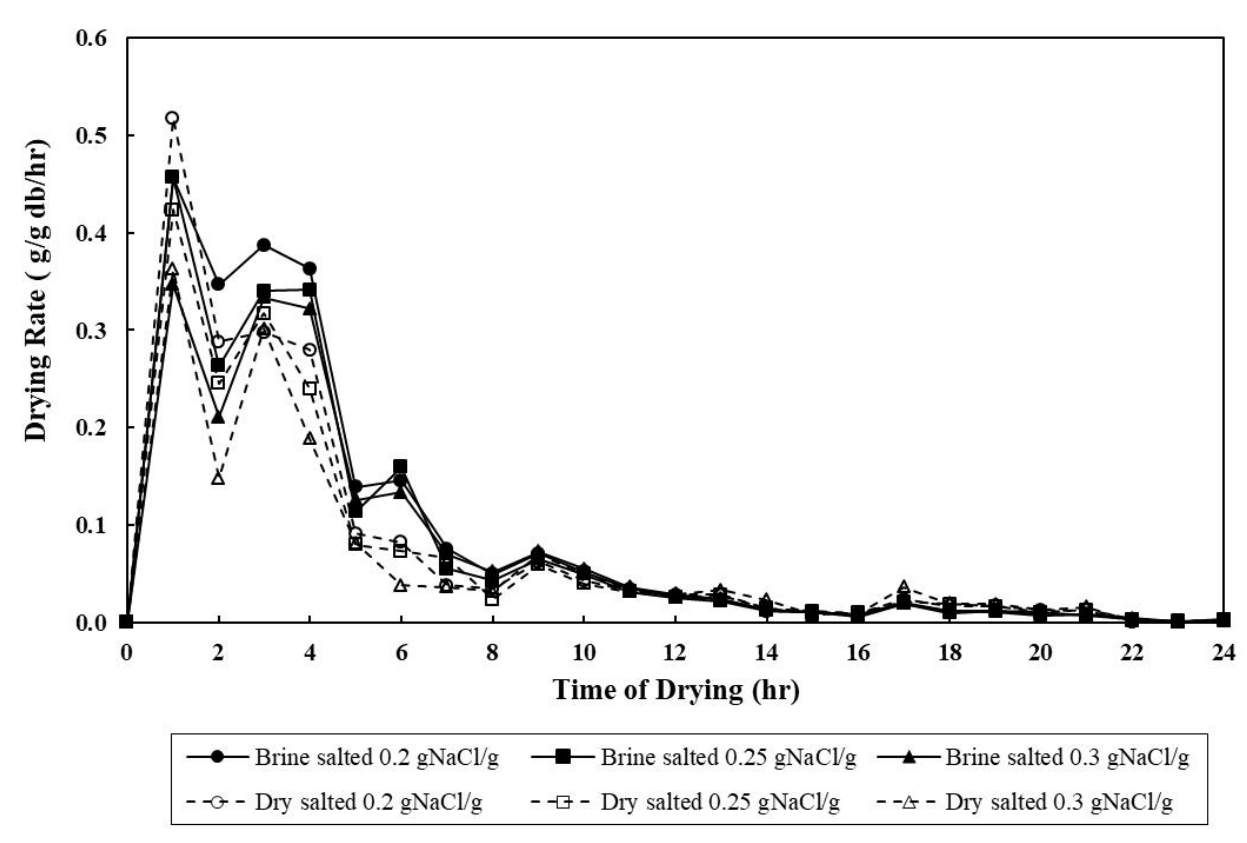

Figure 6 - Drying Rate of Salted Fish Drying

After further drying, the drying rate of dry and brine salted fish tended to be similar. For the brine salting method, the convective heat transfer coefficient decreased with a decrease in the moisture content of the fish (Jain, 2006). The salt concentration of $0.2 \mathrm{~g} \mathrm{NaCl} / \mathrm{g}$ for both salting methods had the fastest drying rate in the first $8 \mathrm{hrs}$ of the drying process, compared with other salt concentrations. This salt concentration is still favoured by traditional processors (Berhimpon et al., 1990).

\section{CONCLUSION}

Drying of salted yellowtail fish using renewable energy in a tropical area was investigated. The drying process was conducted under an active greenhouse solar dryer. The air inside the greenhouse was circulated by a DC exhaust fan and the electrical power was supplied by a solar cell. The performance parameters of drying were the temperature and relative humidity. The greenhouse temperature varied from $32^{\circ} \mathrm{C}$ to $51.4^{\circ} \mathrm{C}$ and the relative humidity varied from $24.9 \%$ to $58.71 \%$. Those temperature and relative humidity were within the recommended range of values for fish drying i.e do not exceed $70^{\circ} \mathrm{C}$ for temperature and $10-40 \%$ for relative humidity.

Testing of the dryer was carried out to examine the effect of fish salting treatment on the moisture ratio and drying rate of fish under the greenhouse dryer. Two different methods were used for salting the fish, brine salting and dry salting. Both of these salting methods were investigated using different salt concentrations. The brine salting method showed a better drying rate and moisture content reduction than the dry salting method. For both salting methods, the lowest salt concentration of $0.2 \mathrm{gNaCl} / \mathrm{g}$ is recommended as it showed faster moisture content reduction and drying rate in the first $8 \mathrm{hr}$ of the drying process. The highest salt concentration of $0.3 \mathrm{~g} \mathrm{NaCl} / \mathrm{g}$ for the dry salting method is not recommended as it had a slower drying rate.

\section{REFERENCES}

1. Bala, B. K. and Mondol, M. R. A. (2001) "Experimental Investigation on Solar Drying of Fish Using Solar Tunnel Dryer," Drying Technology, 19(2), pp. 427-436.. 
2. Bellagha, S., Sahli, A., Farhat, A., Kechaou, N. and Glenza, A. (2007) "Studies on salting and drying of sardine (Sardinella aurita): Experimental kinetics and modeling," Journal of Food Engineering, 78(3), pp. 947-952..

3. Berhimpon, S., Souness, R. A., Buckle, K. A. and Edwards, R. A. (1990) "Salting and drying of yellowtail (Trachurus mccullochi Nichols)," International Journal of Food Science \& Technology, 25(4), pp. 409-419..

4. Darvishi, H., Azadbakht, M., Rezaeiasl, A. and Farhang, A. (2013) "Drying characteristics of sardine fish dried with microwave heating," Journal of the Saudi Society of Agricultural Sciences. King Saud University, 12(2), pp. 121-127..

5. Fisheries, F. A. O. (2013) "FAO Global Capture Production database updated to 2013 Summary information Fisheries and Aquaculture Department," pp. 1-5.

6. Greenspan, L. (1977) "Humidity fixed points of binary saturated aqueous solutions," Journal of Research of the National Bureau of Standards Section A: Physics and Chemistry, 81A(1), p. 89..

7. Hubackova, A., Kucerova, I., Chrun, R., Chaloupkova, P. and Banout, J. (2014) "Development of Solar Drying Model for Selected Cambodian Fish Species," The Scientific World Journal, 2014, pp. 1-10..

8. Jain, D. (2006) "Determination of Convective Heat and Mass Transfer Coefficients for Solar Drying of Fish," 94, pp. 429-435.

9. Mujaffar, S. and Sankat, C. K. (2005) "The air drying behaviour of shark fillets," Canadian Biosystems Engineering / Le Genie des biosystems au Canada, 47(June).

10. Rahman, M. S. (2006) "Drying of Fish and Seafood," in Mujumdar, A. S. (ed.) Handbook of Industrial Drying. 3rd Editio. Boca Raton, Florida: CRC Press, pp. 547-562.

11. Sidhi, S. D. P., Pujianto, A., Prasetyo, D. and Muhfizar (2017) "Studi Eksperimen untuk Kondisi Tanpa Beban pada Pengering Ikan Tipe Greenhouse Aktif," 6(2), pp. 43-47.

12. Sobukola, O. P. and Olatunde, S. O. (2011) "Effect of salting techniques on salt uptake and drying kinetics of African catfish (Clarias gariepinus)," Food and Bioproducts Processing, 89(3), pp. 170-177.

13. Tiwari, S., Tiwari, G. N. and Al-Helal, I. M. (2016) "Development and recent trends in greenhouse dryer: A review," Renewable and Sustainable Energy Reviews. Elsevier, 65, pp. 1048-1064. 